\title{
Analysis of pathogens and their susceptibility in patients with diabetic foot syndrome treated surgically
}

\section{ABSTRACT}

Introduction. Diabetes is one of the most common civilization diseases, which has a significant impact on particular individuals but also on society as a whole. Improper metabolism of sugars can lead to a number of complications affecting the whole body. From a surgical point of view treatment of diabetes complications, apart from optimizing the treatment of hyperglycaemia, is limited to the treatment of diabetic foot syndrome. The syndrome develops on a basis of microneuropathy, leading to development of necrotic lesions which are the perfect breeding ground for a number of bacteria. Adequate antibiotic therapy is one of the most important elements of all interdisciplinary therapy in treatment of diabetic foot syndrome.

Material and methods. In the present study, results of obtained swab cultures were evaluated to assess optimal antibiotic treatment, evaluating only the first bred isolate from the patient.

Results. In all 61 patients inflammatory infiltration of skin and soft tissues was observed, most of which accompanied by foot/leg wounds that healed after minor surgical interventions. A single pathogen was isolated in nearly half of the patients. In one patient, eight pathogens were isolated. The most commonly identified pathogens

Address for correspondence:

lek. Paweł Kumoniewski

Klinika Chirurgii Ogólnej i Onkologicznej

CSK UM w Łodzi

ul. Pomorska 251, 92-213 Łódź

Phone: 4220143 70, 663304746

Fax: 422014371

e-mail: pawel.kumoniewski@gmail.com

Translation: lek. Jędrzej Toczko

Clinical Diabetology 2017, 6, 6, 189-194

DOI: 10.5603/DK.2017.0031

Received: 05.10.2017

Accepted: 04.12.2017 were Staphylococcus aureus, Enterococcus faecalis, Coagulase-negative staphylococcus (other than S. Cohni, S. Epidermidis, S. Werneri, S. Haemoliticus).

Conclusions. Soft tissue infections in the diabetic foot syndrome are most frequently caused by several types of bacteria, most commonly Staphylococcus aureus. Based on the provided results, it appears that the optimal start of antibiotic therapy would be the use of amoxicillin with clavulanic acid. (Clin Diabetol 2017; 6, 6: 189-194)

Key words: diabetes, diabetic foot, diabetic complications, diabetic foot infections, amputation

\section{Introduction}

Diabetes is a health problem of great social significance in both developing and developed economies [1]. Patients with pyo-necrotic wounds of the feet make up a great portion of surgical wards referrals. These lesions are most frequently a result of complications of chronic or newly diagnosed diabetes. Pyo-necrotic wounds develop on a basis of progressive neuro- and angiopathy [2]. They can occur anywhere in the body, but are most commonly observed within lower extremities, mainly feet. These lesions may also be caused by tissue necrolysis due to atherosclerosis, or, rarely, by insect or animal bite related infections [3]. Purulent infections mostly affect soft tissues, especially subcutaneous tissue, and seldomly penetrate to the bone. At first, skin and subcutaneous tissue hypertonicity along with swelling, redness, local hyperthermia and pain - classic symptoms of inflammation - are observed.

An untreated inflammatory infiltration spreads within the tissues, finally leading to phlegmon or separated abscesses formation. Undiagnosed or improperly 
treated purulent lesions may lead to development of full blown sepsis [4], resulting in death of the patient. Appropriate treatment of increased glycaemia - which often exceeds $500 \mathrm{mg} / \mathrm{dl}$ - is the initial therapy. Interdisciplinary cooperation between surgeons and diabethologists is a must in these situations. A 24 hour glycaemic profile along with constant intravenous insulin administration and immediate adjustments to glucose levels as well as daily, multiple dressing changes, are part of a successful treatment. Surgical approach includes mainly phlegmon debridement with wide, multiple cuts of skin and subcutaneous tissue. These procedures aim to drain pus from tissues and remove demarcated necrotic tissue [5]. It is often necessary to make additional cross-cuts to allow flow drainage or manual rinsing of purulent lesions. Afflicted extremities should be immobilized and elevated.

The third, indispensable part of therapy is supportive antibiotic treatment - empiric and broad spectrum at first and, subsequently, targeted after culture results are obtained. Satisfactory therapeutic effects were observed when vacuum therapy was administered [6]. A hermetic vacuum dressing is put on a tissue debrided of necrotic tissue. Its goal is to simultaneously provide humid surroundings contributory to wound healing, suction of infected content and closing of exposed wound margins, thus preventing excessive scar formation. Using VAC - Vacuum Assisted Closure - allows reducing painful sensations related to dressing changes, which are then performed every 3 or 4 days [7]. Unfortunately, not every appropriate treatment results in preservation of the whole limb. Tissue infections in course of diabetic foot syndrome are the most common cause of atraumatic amputations in Poland as well as Europe and the USA [8].

\section{Aim of the study}

The main aim of this study is to asses the incidence, antibiograms and drug resistance of pathogens cultivated from pyo-necrotic lesions in course of diabetic foot in patients treated in the Department of General and Oncological Surgery. Another aim is to compare the results with statistical assessment of hospital drug resistance in the Department of General and Oncological Surgery.

\section{Material and methods}

The study included patients admitted because of pyo-necrotic lesions in course of the diabetic foot syndrome in the General and Oncological Surgery Clinic of the Medical University in Lodz from 01/09/2014 to $31 / 08 / 2016$ - a two year observation period. Patients with lesions of the feet of angiopathic origin were also included in the study.
A total of 61 patients were treated during that time because of the aforementioned reason, which represents $3 \%$ of all patients hospitalized in this period.

The vast majority of patients were male $-82 \%, 50$ of 61 total - whereas $18 \%-11$ of 61 total - were female. Most of the patients (90\%) were patients with longstanding type 2 diabetes, 15\% of them were treated with secondary insulin therapy. Glucose levels upon admission varied from $200 \mathrm{mg} / \mathrm{dl}$ to $580 \mathrm{mg} / \mathrm{dl}$ with a mean value of $330 \mathrm{mg} / \mathrm{dl}$. The most common comorbidities were generalized atherosclerosis (80\%) and stage III chronic kidney failure (65\%).

Osteolysis of phalanxes and distal parts of mid-foot was exposed in 2 x-ray projections in each case. Exemplary $x$-ray images are presented in Figures 1 and 2 .

47 of 61 patients $(77 \%)$ required a single admission. 13 patients $(21 \%)$ needed two hospitalizations, whereas one patient required four hospital stays to either heal over the lesions of the feet or improve enough to continue treatment in outpatient care.

Mean length of stay in the studied group was 15.4 days -63 days in one case. The median hospitalization length was 12 days.

Bacterial culture results from pyo-necrotic lesions that required surgical debridement were assessed. The swabs were collected from deep layers of soft tissues during surgical debridement of pyo-necrotic lesions.

Only the first cultivated strain of each species was analyzed for each patient, another isolates of the same species were not taken into consideration.

The results were correlated with statistical assessment of in-hospital pathogen drug resistance in General and Oncological Surgery Clinic, Clinical and Education Centre of Medical University in Lodz, performed by the Division of Nosocomial Infections.

Amoxicilin and clavulanic acid administered intravenously were used as the first line of treatment.

\section{Results}

Admitted patients presented pyo-necrotic lesions of various severity as well as increased glycaemia. However, 40 of 60 patients (66\%) reported a primary, minimal chafing, mainly in the metatarsophalangeal joint of the hallux, a minor cut or having trod on a sharp object, as well as having their nails cut too deeply. Subsequently, problems with glycaemic control followed. Delay in seeking hospital treatment causes self-perpetuating, fast propagation of pyo-necrotic lesions.

A various degree of inflammatory infiltration of the skin and soft tissues of lower limbs was observed in all patients upon admission. In most cases - 37 of $61,61 \%$ of the patients - the infiltration was accom- 


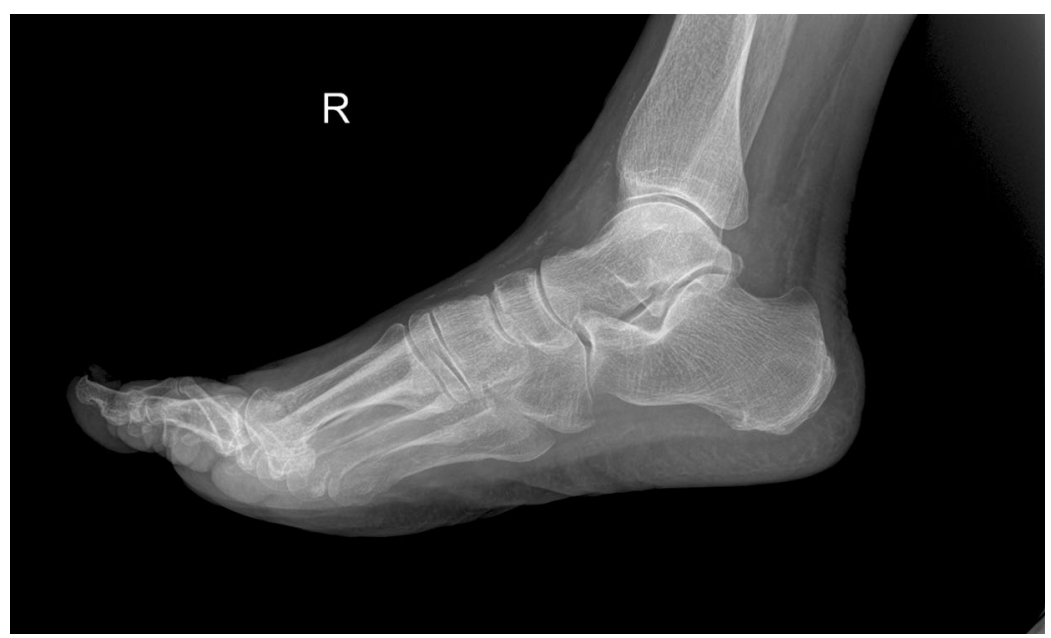

Figure 1. An X ray of a diabetic foot syndrome - lateral projection. Calcifications of the dorsal pedal artery are visible

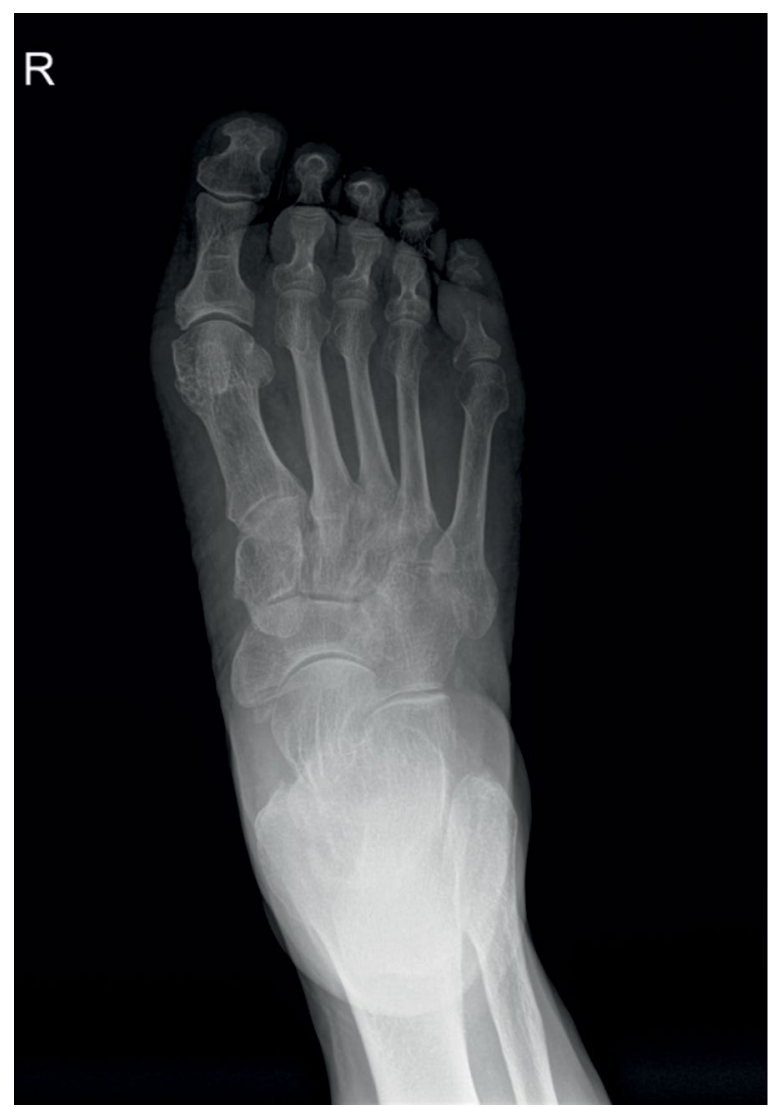

Figure 2. An $X$ ray of a diabetic foot syndrome patient in AP projection. Signs of osteolysis within the proximal interphalangeal joint of the foot and its bone structures are visible

panied by feet and crura lesions, which healed after single surgical debridement and further conservative treatment - empiric antibiotic therapy, followed by targeted therapy based on culture results. No additional surgical interventions were necessary.
Table 1. Number of pathogens isolated from pyo-necrotic lesion during hospital stay

\begin{tabular}{lc}
\hline & $\begin{array}{c}\text { Patients with pathogens isolated/total } \\
\text { number of patients }(\mathbf{N}=61)\end{array}$ \\
\hline 1 pathogen & $29(47.54 \%)$ \\
2 pathogens & $19(31.15 \%)$ \\
3 pathogens & $7(11.48 \%)$ \\
4 pathogens & $3(4.92 \%)$ \\
6 pathogens & $0(0 \%)$ \\
7 pathogens & $1(1.64 \%)$ \\
8 pathogens & $1(1.64 \%)$ \\
\hline
\end{tabular}

18 patients (29\%) required multiple surgical procedures. Below-knee amputation was necessary in 5 cases ( $8 \%$ ) due to lesion advancement, no healing after debridement or coexisting advanced vasculary disorders in the extremities. One patient $(1.6 \%)$ required an above-knee amputation.

In 29 cases $(47.5 \%)$ a single pathogen was bred in cultures obtained from pyo-necrotic lesions. Eight pathogens were observed in one case (1.6\%). Pathogen number distribution is presented in Table 1.

In the study group Staphylococcus aureus was the most commonly identified pathogen, as it was isolated in 26 patients (42.62\%). The second most frequent pathogen, observed in 11 patients (18\%) was Enterococcus faecalis, the third most frequent being a coagulase negative Staphylococcus other than S. Cohni, S. Epidermidis, S. Werneri, S. Haemoliticus, isolated in 10 cases (16.4\%). A detailed distribution of obtained pathogen cultures and their drug resistance are presented in Tables 2 and 3. 
Table 2. Incidence of respective pathogens isolated in swab cultures from pyo-necrotic lesions

\begin{tabular}{|c|c|c|}
\hline Pathogen & Number of pathogens isolated/total number of patients $(N=61)$ & $\%$ \\
\hline Staphylococcus aureus & 26 & $42.62 \%$ \\
\hline Enterococcus faecalis & 11 & $18.03 \%$ \\
\hline Coagulase negative staphylococcus & 10 & $16.39 \%$ \\
\hline Streptococcus agalactiae & 8 & $13.11 \%$ \\
\hline Pseudomonas aeruginosa & 7 & $11.48 \%$ \\
\hline Streptococcus pyogenes & 7 & $11.48 \%$ \\
\hline Escherichia coli & 6 & $9.83 \%$ \\
\hline Proteus mirabilis & 6 & $9.83 \%$ \\
\hline Klebsiella pneumoniae & 5 & $8.20 \%$ \\
\hline Acinetobacter baumannie complex & 4 & $6.56 \%$ \\
\hline Enterobacter cloacae complex & 3 & $4.92 \%$ \\
\hline Morganella morganii & 3 & $4.92 \%$ \\
\hline Sternotrophomonas maltophilia & 2 & $3.28 \%$ \\
\hline Acinetobacter species & 2 & $3.28 \%$ \\
\hline Streptococcus group C & 2 & $3.28 \%$ \\
\hline Serratia maercescens & 2 & $3.28 \%$ \\
\hline Proteus penneri & 2 & $3.28 \%$ \\
\hline Candida albicans & 1 & $1.64 \%$ \\
\hline Citrobacter braakii & 1 & $1.64 \%$ \\
\hline Proteus vulgaris & 1 & $1.64 \%$ \\
\hline Pseudomonas putida & 1 & $1.64 \%$ \\
\hline Veilinella species & 1 & $1.64 \%$ \\
\hline Serratia fonticola & 1 & $1.64 \%$ \\
\hline Staphylococcus cohni & 1 & $1.64 \%$ \\
\hline Staphylococcus epidermidis & 1 & $1.64 \%$ \\
\hline Streptococcus species & 1 & $1.64 \%$ \\
\hline Streptococcus mitis & 1 & $1.64 \%$ \\
\hline Staphylococcus werneri & 1 & $1.64 \%$ \\
\hline Staphylococcus haemoliticus & 1 & $1.64 \%$ \\
\hline
\end{tabular}

In a single case only, a fungal culture was isolated - Candida albicans of Candida species, susceptible to amfotericin B, flucotsine, capsofungin, micafungin and voriconazole.

\section{Discussion}

Patients admitted to hospital due to diabetic foot syndrome as a complication of decompensated diabetes or because of lower extremities infections in newly diagnosed diabetes, pose a compelling health problem. This manifests as a need of long term hospitalizations, multidisciplinary, collective treatment, oftentimes in several different hospital wards. Diabetes therapy alone, combined with multiple surgical procedures and frequent use of expensive antibiotics and vacuum dressings, situate diabetic foot syndrome treatment quite high among the ranks of cost-intensiveness.
Considering the results of this study it must be highlighted, that in most cases quick glycaemia stabilization allows a single surgical intervention to be sufficient to result in wound healing. However in almost $40 \%$ of the cases multiple surgical procedures are necessary, including eventual limb amputation.

Bacterial cultures resulted in one or more pathogens isolated in all studied cases. Staphylococcus aureus was the most commonly bred bacteria and in all cases, was susceptible to amoxicilin with clavulonic acid, Ceftaroline, Cefuroxime, Ertapenem, Teicoplanin, Tigecycline, and Linezolid. Initial treatment with amoxicilin and clavulanic, one of eight antibotics to which the pathogen is $100 \%$ susceptible, appears to be the best choice of first line of treatment in infections caused by this pathogen. This $\beta$-lactam antibiotic combined with a $\beta$-lactamase inhibitor has a broad spectrum of 
Table 3. Susceptibility of six pathogens most commonly isolated from pyo-necrotic lesions in diabetic foot syndrome patients hospitalized in the General and Oncological Surgery

\begin{tabular}{|c|c|c|c|c|c|c|}
\hline \multirow[t]{2}{*}{ Antimicrobial agent } & \multicolumn{6}{|c|}{$\%$ of susceptible strains $/ \%$ of resistant and intermediately resistant strains } \\
\hline & $\begin{array}{c}\text { Staphylococcus } \\
\text { aureus }\end{array}$ & $\begin{array}{c}\text { Enterococcus } \\
\text { faecalis }\end{array}$ & $\begin{array}{c}\text { Coagulase } \\
\text { negative } \\
\text { Staphylococcus }\end{array}$ & $\begin{array}{c}\text { Streptococcus } \\
\text { agalactiae }\end{array}$ & $\begin{array}{c}\text { Pseudomonas } \\
\text { aeruginosa }\end{array}$ & $\begin{array}{c}\text { Streptococcus } \\
\text { pyogenes }\end{array}$ \\
\hline Amikacun & $75 / 25$ & $100 / 0$ & $-1-$ & $-1-$ & $71 / 29$ & $-1-$ \\
\hline Amoxicilin/clavulanic acid & $100 / 0$ & $100 / 0$ & $-1-$ & $100 / 0$ & $-1-$ & $-1-$ \\
\hline Ampicilin & $-1-$ & $100 / 0$ & $-1-$ & $100 / 0$ & $-1-$ & $-1-$ \\
\hline Aztreonam & $-1-$ & $-1-$ & $-1-$ & $-1-$ & $0 / 100$ & $-1-$ \\
\hline Cefepim & $-1-$ & $100 / 0$ & $-1-$ & $-1-$ & $71 / 29$ & $-1-$ \\
\hline Cefotaxsim & $-1-$ & $100 / 0$ & $-1-$ & $100 / 0$ & $-1-$ & $100 / 0$ \\
\hline Ceftaroline & $100 / 0$ & $-1-$ & $-1-$ & $100 / 0$ & $-1-$ & $100 / 0$ \\
\hline Ceftazidime & $-1-$ & $100 / 0$ & $-1-$ & $-/-$ & $86 / 14$ & $-/-$ \\
\hline Ceftriaxone & $-1-$ & $-1-$ & $-1-$ & $100 / 0$ & $-1-$ & $100 / 0$ \\
\hline Cefuroxime & $100 / 0$ & $-1-$ & $-1-$ & $100 / 0$ & $-1-$ & $-1-$ \\
\hline Ciprofloksacin & $85 / 15$ & $100 / 0$ & $60 / 40$ & $-1-$ & $71 / 29$ & $-1-$ \\
\hline Daptomycin & $100 /-$ & $-1-$ & $83 / 17$ & $-1-$ & $-1-$ & $-1-$ \\
\hline Ertapenem & $100 /-$ & $-1-$ & $-1-$ & $-1-$ & $-1-$ & $-1-$ \\
\hline Erythromycin & $72 / 28$ & $-1-$ & $40 / 60$ & $63 / 37$ & $-1-$ & $100 / 0$ \\
\hline Gentamicin & $89 / 11$ & $80 / 20$ & $80 / 20$ & $-1-$ & $71 / 29$ & $-1-$ \\
\hline Gentamicin 120 & $-1-$ & $50 / 50$ & $-1-$ & $-1-$ & $-1-$ & $-1-$ \\
\hline Imipenem & $-1-$ & $100 / 0$ & $-1-$ & $-1-$ & $86 / 14$ & $-1-$ \\
\hline Clindamycin & $72 / 28$ & $-1-$ & $50 / 50$ & $63 / 37$ & $-1-$ & $100 / 0$ \\
\hline Colistin & $-1-$ & $100 / 0$ & $-1-$ & $-1-$ & $100 / 0$ & $-1-$ \\
\hline Levofloxacin & $85 / 15$ & $83 / 17$ & $60 / 40$ & $100 / 0$ & $67 / 33$ & $86 / 14$ \\
\hline Linezolid & $100 / 0$ & $100 / 0$ & $100 / 0$ & $100 / 0$ & $-1-$ & $100 / 0$ \\
\hline Meropenem & $-1-$ & $100 / 0$ & $-1-$ & $-1-$ & $100 / 0$ & $-1-$ \\
\hline Moxifloksacin & $70 / 30$ & $-/-$ & $67 / 33$ & $-1-$ & $-1-$ & $-1-$ \\
\hline Netilmicin & $-1-$ & $-1-$ & $-1-$ & $-1-$ & $50 / 50$ & $-1-$ \\
\hline Nitrofurantoin & $-1-$ & $100 / 0$ & $-1-$ & $-1-$ & $-1-$ & $-1-$ \\
\hline Oksacilin & $80 / 20$ & $-1-$ & $30 / 70$ & $-1-$ & $-1-$ & $-1-$ \\
\hline Penicilin & $-1-$ & $-1-$ & $0 / 100$ & $100 / 0$ & $-1-$ & $100 / 0$ \\
\hline Piperacilin & $-1-$ & $100 / 0$ & $-1-$ & $-1-$ & $71 / 29$ & $-1-$ \\
\hline Piperacilin/Tazobactam & $-1-$ & $100 / 0$ & $-1-$ & $-1-$ & $71 / 29$ & $-1-$ \\
\hline Quinpristin/Dalphopristin & $100 / 0$ & $-1-$ & $100 /-$ & $-1-$ & $-1-$ & $-1-$ \\
\hline Rifampicin & $93 / 7$ & $-1-$ & $86 / 14$ & $-1-$ & $-1-$ & $-1-$ \\
\hline Streptomycin 300 & $-1-$ & $67 / 34$ & $-1-$ & $-1-$ & $-1-$ & $-1-$ \\
\hline Teicoplanin & $100 / 0$ & $100 / 0$ & $60 / 40$ & $100 / 0$ & $-1-$ & $-1-$ \\
\hline Tetracycline & $77 / 23$ & $-1-$ & $50 / 50$ & $13 / 87$ & $-1-$ & $86 / 14$ \\
\hline Ticarcillin/Clavulanic acid & $-1-$ & $-1-$ & $-1-$ & $-1-$ & $57 / 43$ & $-1-$ \\
\hline Tigecycline & $100 / 0$ & $100 / 0$ & $100 / 0$ & $-1-$ & $-1-$ & $-1-$ \\
\hline Tobramycun & $-1-$ & $100 / 0$ & $-1-$ & $-1-$ & $71 / 29$ & $-1-$ \\
\hline Trimethoprim/ & $92 / 8$ & $17 / 83$ & $60 / 40$ & $100 / 0$ & $0 / 100$ & $100 / 0$ \\
\hline /Sulfamethoksazol & & & & & & \\
\hline Vankomycin & $100 / 0$ & $100 / 0$ & $100 / 0$ & $100 / 0$ & $-1-$ & $100 / 0$ \\
\hline
\end{tabular}

antimicrobial activity. It is particularly useful in treating aerobic-anaerobic infections of mixed origin. Amoxicilin exhibits good penetration into pus, synovial fluid, as well as into bile, peritoneal fluid, middle ear, pleural fluid, uterus and ovaries. Its high concentration is observed in bones, urine, bronchial mucosa and sputum [9]. This antibiotic can be safely applied in patients with concomitant diabetic kidney disease and may only require 
dose reduction when creatinine clearance is below $30 \mathrm{ml} /$ /min. The possibility of sequential therapy and its low cost are also not to be overlooked. A week of treatment with 2 doses of 1 gram daily - $875 \mathrm{mg}$ of amoxicilin and $125 \mathrm{mg}$ of calvulanic acid - costs below 5 euros. Additionally, amoxicilin can also be taken orally, making follow up treatment in an outpatient setting available. Despite having many advantages, amoxicilin is not without its adverse effects. A long term treatment may cause digestive afflictions, but also pruritus, macular rash or urticaria. Rarely, an increase in liver enzymes and bilirubin levels, hepatitis with jaundice, as well as leucopenia, thrombocytopenia, and haemolytic anemia may occur.

Amongst other antibiotics equally effective against the isolated microbe, linezolid is also worth mentioning. This oxazolidinone antibiotic displays a broader spectrum of effect against areobic Gram (+) bacteria, some Gram (-) bacteria and anaerobic pathogens [10]. However, its price is many times higher than the price of previously addressed combination of amoxicillin with clavulanic acid. A week lasting treatment with 2 daily doses of $600 \mathrm{mg}$ costs approximately 1000 euros. There is no orally active analogue, so a full course of treatment must be administered during hospital stay. The maximal treatment duration is 28 days.

In almost one in five patients (18\%) Enterococcus faecalis was isolated, being - similarly to Staphylococcus aureus - susceptible to amoxicilin with calvulanic acid and following eighteen chemotherapeutics, i.a Amikacin, Ampicilin, Cefepime, Cefotaxime, Ceftazidime, Ciprofloxacin, Colistin, Linezolid, Imipenem, Meropenem, Nitrofurantoin, Piperacilin, Teicoplanin, Tigecycline, Tobramycin and Vancomycin. Thus, many more therapeutic options are available based on antibiogram results than in the case of Staphylococcus Aureus. The third most commonly bred pathogen - a coagulase negative Staphylococcus, $16.4 \%$ of all patients - leaves us with only three therapeutic options, all of which are administered intravenously: Linezolid, Tigecycline and Vancomycin.

It must be strongly emphasized that infections of pyo-necrotic lesions assessed in this study were - in $31 \%$ of cases - caused by two pathogens, and in $11 \%$ of cases - by three pathogens. Less than $50 \%$ of patients had a single bacteria species isolated. Infections of mixed origin greatly impede the course of treatment and generate additional costs at the same time.

In a "Susceptibility Analysis for General and Oncological Surgery Clinic of the Medical University in Lodz in 2015" [11] report released by the Division of Nosocomial Infections, the most commonly isolated pathogens were Escherichia coli and Staphylococcus aureus. The report concerned all infections that occurred in the clinic. Its conclusions were partly consistent with results of the present study - Staphylococcus aureus was the most frequently isolated pathogen in both analyses. However, following order of incidence was slightly different. Susceptibility conclusions were mostly similar.

The results of this study remain consistent with the results of different works presented both in Europe and globally [12].

\section{Conclusions}

1. Infections caused by more than one pathogen are most common in course of diabetic food syndrome $-52.5 \%$ of the cases

2. Development of pyo-necrotic lesions appears to be of mostly bacterial origin. Only $1.64 \%$ of patients exhibited synchronic yeast infection.

3. The pathogen most commonly isolated from pyonecrotic lesions in diabetic foot syndrome patients is Staphylococcus aureus.

4. An empiric, efficient and economically viable treatment with combination of amoxicillin and clavulanic acid can be proposed in therapy of infected pyo-necrotic lesions in diabetic foot syndrome.

\section{REFERENCES}

1. Toumi A, Bernard L, Chakroun M. Antibiothérapie des infections du pied diabétique. RevTunInfectiol. 2011; 5: 61-67.

2. Sieradzki J, Kblik T. Zespół stopy cukrzycwej, VM Media Sp. z . z o o., Gdańsk 2008.

3. Porzycki P, Dzierżanowska D. Chirurgia Noszczyka, Rozdz. 17: Zakażenia w chirurgii: 200-234.

4. Leiblein M, Marzi I, Sander AL, et al. Necrotizing fasciitis: treatment concepts and clinical results. Eur J Trauma Emerg Surg. 2017 [Epub ahead of print], doi: 10.1007/s00068-017-0792-8, indexed in Pubmed: 28484782.

5. Datsenko BM, Belov SG, Girka El. Surgical treatment of purulent necrotic complcations in patients with diabetic foot syndrome. Klin Khir. 2001; 8: 10-12.

6. Liu Si, He CZ, Cai YT, et al. Evaluation of negative-pressure wound therapy for patients with diabetic foot ulcers: systematic review and meta-analysis. Ther Clin Risk Manag. 2017; 13: 533-544, doi: 10.2147/TCRM.S131193, indexed in Pubmed: 28458556.

7. Ford-Dunn S. Use of vacuum assisted closure therapy in the palliation of a malignant wound. Palliat Med. 2006; 20(4): 477-478, doi: 10.1191/0269216306pm1117cr, indexed in Pubmed: 16875120.

8. Ha Van G, Hartemann-Heurtier A, Gautier F, et al. Pied diabétique. Encycl Med Chir Endocrinologie-Nutrition. 2011; 10: 366-369.

9. https://bazalekow.mp.pl/leki/doctor_subst.html?id=89.

10. https://bazalekow.mp.pl/leki/doctor subst.html?id=4063.

11. Analiza lekowrażliwości za 2015 rok dla Kliniki Chirurgii Ogólnej i Onkologicznej USK im. WAM-CSW w Łodzi. dr n. med. G. Woch - Pracownia Mikrobiologii ZDL i BK.

12. liro HJ, Hagberg L, Forsblom E, et al. Microbiological Etiology and Treatment of Complicated Skin and Skin Structure Infections in Diabetic and Nondiabetic Patients in a Population-Based Study Open Forum Infect Dis. 2017; 4(2). 